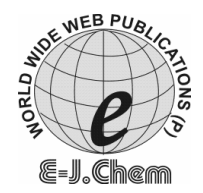

ISSN: 0973-4945; CODEN ECJHAO

E-Journal of Chemistry

http://www.e-journals.net

\title{
A Novel Method to Prepare PolyGMA and its Application to Immobilization of $\boldsymbol{\beta}$-Galactosidase
}

\author{
SUN SUFANG ${ }^{*}$ and DONG LINGYUN \\ College of Chemistry and Environmental Science, \\ Hebei University, Baoding 071002, China. \\ sunsufang@hbu.edu.cn
}

Received 17 January 2009; Accepted 6 March 2009

\begin{abstract}
The reactive, macroporous and massive epoxy group containing polyGMA was synthesized simultaneously with methanol aqueous solution and nano-calcium carbonate as porogen by bulk copolymerization. After the polymer was smashed, particles with diameters in the range of 0.30 to $0.45 \mathrm{~mm}$ were taken as the carrier and the scanning electron microscopy (SEM) micrographs were done to characterize its surface structure. Under the optimum conditions, $\beta$-galactosidase was immobilized on the supporter obtained above and the enzyme activity bound per gram drier carrier could attained up to $77.33 \%$, which was much higher than that bound on the carrier prepared by only using methanol aqueous solution as porogen. The conclusion obtained indicated that the ployGMA prepared concurrently with liquid and solid porogen was more suitable to immobilize enzyme because of the much more porous surface structure obtained.
\end{abstract}

Keywords : Glycidyl methacrylate bulk polymerization, Nano-calcium carbonate, $\beta$-galactosidase

\section{Introduction}

Enzyme biocatalysts are increasingly used because of the growing demand for biotransformation a high chemo- and stereo-specificity in the fine chemical industries, such as pharmaceuticals, agrochemicals and health care products. However, the application of an enzyme for a given reaction is often hampered by its reusability. This is because free enzyme, as a biocatalyst, is lack of long-term stability under processing conditions and difficult to be recovered and recycled from the reaction mixture, making the reuse of the enzyme impossible. Hence the idea of immobilizing the enzyme on a rigid solid support enabling easy separation and the possibility of operation in a packed bed or fluidized-bed reactor has been of great industrial interest for many years ${ }^{1,2}$. 
$\beta$-Galactosidase ( $\beta$-D-galactosidase galactohydrolase, EC 3.2.1.23) from Aspergillus oryzae, which efficiently catalyzes not only the hydrolysis of the $\beta$-galactoside linkages of lactose to glucose and galactose but also the transgalactosylation reaction to produce galactooligosaccharides, could be immobilized on various supports and by different methods, including covalent attachment to activated supports and adsorption on materials (such as zirconium) surfaces, ion exchange resins acrylic polymers, emulsion membrane reactors, nylon fibres and silica ${ }^{3}$. After immobilization of it, changes were observed in enzyme activity, optimum $\mathrm{pH}$, affinity for substrate and stability. The extent of these changes depends on the source of enzyme, the type of support and the method of immobilization. It is, thus, important that the choice of proper support material and immobilization method over the free bioactive agent should be well justified.

Among all the materials used to immobilize enzyme, epoxy activated carriers seem to be almost ideal systems to develop very easy protocols for enzyme immobilization because epoxy group could exhibit good reactivity under mild conditions and would be very stable at neutral $\mathrm{pH}$ values even in wet conditions ${ }^{4,5}$. In hence, this kind of carriers could be stored for long periods of time and the reactions of epoxy groups in carriers with different nucleophilic groups on the protein surface (e.g., amino, hydroxy or thiol moieties) will be suitable to immobilize enzymes by forming extremely strong linkages (secondary amino bonds, ether bonds and thioether bonds) with minimal chemical modification of the protein ${ }^{6}$.

In this paper, the polyGMA with macroporous morphology, reactive epoxy groups were synthesized successfully by buck polymerization of glycidyl methacrylate (GMA), using $N$, $N$-methylene-2-bis (acrylamide)(MBAA) as a crosslinking agent, a mixture of methanol aqueous solution as liquid pore-forming agents and nano-calcium carbonate as solid one. After the polymer was smashed, particles with diameters in the range of 0.30 to $0.45 \mathrm{~mm}$ were taken as the carrier and characterized by means of SEM method. Then the supporter obtained was employed to immobilize $\beta$-galactosidase from aspergillus oryzae, and the enzyme activity and the activity yield of the immobilized $\beta$-galactosidase was also investigated in order to examine the suitability to immobilize enzyme of the supporter obtained from liquid and solid pore-forming agents.

\section{Experimental}

Ultraviolet spectrotometer (T6 New Century), vacuum desiccator (DZ-6020), digital pH meter (PHS-3C) and water constant temperature oscillator (SHA-B), universal grinder (FW-200) were used for the study. All the aqueous solutions were prepared by twice distilled water. Glycidyl methacrylate (GMA) (99\%) was purchased from Shanghai Jinchao Chemical Co. Ltd. $\beta$-Galactosidase from Aspergillus oryzae $(11.2 \mathrm{U} / \mathrm{mg})$ and $o$ nitrophenyl- $\beta$-D-galactopyranoside (ONPG) were obtained from Sigma. $N, N$-methylene2-bis (acrylamide)(MBAA), azo-bis-isobutyronitrile(AIBN) and other reagents were all analytical grades.

\section{Preparation of enzyme and substrate solution}

$0.1500 \mathrm{~g}$ of $\beta$-galactosidase was weighed and extracted in $25 \mathrm{~mL} 0.1 \mathrm{M}$ sodium phosphate buffer ( $\mathrm{pH}$ 8.0), then the enzyme solution was obtained and stored in the refrigerator for use. The substrate solution was prepared by dissolving $0.0150 \mathrm{~g}$ ONPG in twice distilled water and made up $10 \mathrm{~mL}$ solution. 


\section{Preparation of macroporous glycidyl methacrylate polymer}

The macroporous polyGMA was prepared by buck copolymerization in a reactor of plastic beaker. The reaction system contains a monomer mixture (GMA $1.4 \mathrm{~mL}$, MBAA $2.4000 \mathrm{~g}$ and acrylamide $0.7500 \mathrm{~g}$ ), initiator (AIBN $0.1 \%(\mathrm{w} / \mathrm{w})$ ), $14 \mathrm{~mL}$ methanol aqueous solution as liquid phase porogen (the ratio of inert component to monomer was 10:1) and nanocalcium carbonate $(75 \% \mathrm{w} / \mathrm{w})$ as solid phase porogen. After the mixture was shaked up completely, the reaction was carried out at $70{ }^{\circ} \mathrm{C}$. Then the large pieces of solid obtained were smashed and the particles ranging from 0.30 to $0.45 \mathrm{~mm}$ were taken as the carrier. After being washed with water and ethanol completely, they were kept in acetone for $24 \mathrm{~h}$ to remove the liquid phase porogen and $0.1 \mathrm{M}$ hydrochloric acid solution for $24 \mathrm{~h}$ to get rid of nano-calcium carbonate, and then dried under vacuum. It is notable that, in the following discussion, the supporter only with liquid phase as porogen was called supporter I and the one simultaneously with liquid and solid porogen was called supporter $\mathbb{I}$.

\section{Method of immobilization}

The immobilization was carried out by adding an amount of polymer particles $(0.0500 \mathrm{~g})$ to $0.5 \mathrm{~mL} 0.1 \mathrm{M}$ phosphate buffer $(\mathrm{pH} 8.0)$ containing enzyme $(6 \mathrm{mg} / \mathrm{mL})$. With gently stirring, the reaction was allowed to proceed at $25^{\circ} \mathrm{C}$. After 24 hours, the immobilized enzyme was filtered and washed with $0.1 \mathrm{M}$ phosphate buffer ( $\mathrm{pH}$ 5.0) until no protein was detected. The enzyme bound on the supporter I was called the immobilized enzyme I, and that bound on the supporter II was called Immobilized Enzyme II .

Enzyme activity assay

The activity of the free and the immobilized enzyme were determined according to the references $^{7,8}$ using ONPG as a substrate. For the free enzyme activity, aliquots of it $(0.1 \mathrm{~mL})$ were added to the mixture of $0.9 \mathrm{~mL} 0.1 \mathrm{M}$ phosphate buffer (pH 5.0) and $0.2 \mathrm{~mL}$ ONPG $(1.5 \mathrm{mg} / \mathrm{mL})$. After being incubated at $55^{\circ} \mathrm{C}$ for $2 \mathrm{~min}$, the reaction of ONPG was stopped by the addition of $2 \mathrm{~mL} 1 \mathrm{M} \mathrm{Na}_{2} \mathrm{CO}_{3}$ solution, and the amount of ONP was measured directly at $405 \mathrm{~nm}$. For the immobilized enzyme activity, $0.0500 \mathrm{~g}$ of the immobilized enzyme was soaked in $1 \mathrm{~mL} 0.1 \mathrm{M}$ phosphate buffer, the reaction was started by adding 0.2 $\mathrm{mL}$ ONPG $(1.5 \mathrm{mg} / \mathrm{mL})$. After being carried out for $15 \mathrm{~min}$ at $55{ }^{\circ} \mathrm{C}$, the reaction was stopped and analyzed as above. The activity yield was calculated as the ratio of immobilized enzyme to enzyme subjected to immobilization. One unit of activity was defined as the amount of enzyme that liberated $1 \mu \mathrm{mol}$ of product $/ \mathrm{min}$ at $55^{\circ} \mathrm{C}$.

\section{Results and Discussion}

\section{Process to make macroporous glycidyl methacrylate polymers}

According to the references ${ }^{9,10}$, the supporter I only with a mixture of methanol and distilled water $(14 \mathrm{~mL}$ and $4.5 \mathrm{~mL})$ as liquid porogen was prepared, and the supporter $\mathbb{I}$, which not only applied the same liquid mixture but also taken nano-calcium carbonate $(75 \% \mathrm{w} / \mathrm{w})$ as porogen, was prepared also, in order to further increase the surface of the polymer and make fully use of the activated epoxy. During the preparation of the supporter $\mathbb{I}$, the amount of nano-calcium carbonate added on the properties of supporter was discussed and the effect was obtained by determining the enzyme activity bounded on the supporter, the results were shown in Figure 1. From the Figure 1, it could be seen, with the increase of nanocalcium carbonate, the activity of the bound enzyme firstly increased then decreased. 
When the quantization of nano-calcium carbonate was $75 \%$ monomer, the enzyme activity obtained was the highest. This perhaps could be explained by the following facts, at the first, the specific surface of the polymer increased with the increase of nano-calcium carbonate, but when the quantization of the nano-calcium added was too much, the structure of the polyGMA overlapped and the surface decreased accordingly. So in our discussion, $75 \%$ nano-calcium carbonate of monomer was selected in the preparation of supporter II .

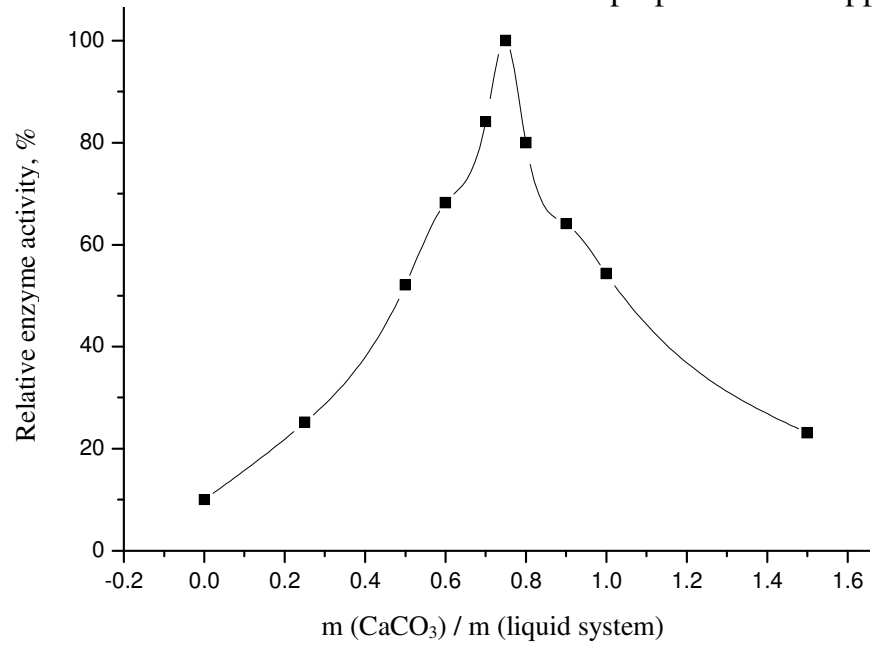

Figure 1. Effect of enzyme activity bounded on the supporter.

\section{Process to immobilize $\beta$-galactosidase}

Four factors, such as enzyme concentration, temperature, reaction time, and $\mathrm{pH}$, were investigated during the immobilization of enzyme. Firstly, various enzyme concentrations were added into the reaction system, and the results determined (Figure 2) showed that the enzyme activity increased at first, then kept nearly constant. Considering both higher enzyme activity and activity yield, $1 \mathrm{~mL}$ enzyme solution $(6 \mathrm{mg} / \mathrm{mL})$ per $0.1 \mathrm{~g}$ dry carrier for the supporter II was taken in the later investigation. Secondly, the influence of $\mathrm{pH}$ on the immobilization of $\beta$-galactosidase was studied in the range of 5.0-9.0, and the activity of the immobilized enzyme was the highest at $\mathrm{pH}$ 8.0. Then, various coupling time from $12 \mathrm{~h}$ to $30 \mathrm{~h}$ was investigated at $25^{\circ} \mathrm{C}$ and the results showed $24 \mathrm{~h}$ was the best selection based on the highest enzyme activity in our reaction system. Finally, the influence of temperature on the enzyme immobilization was studied varying temperature over the range of $20{ }^{\circ} \mathrm{C}$ to $40{ }^{\circ} \mathrm{C}$ and the results showed that the enzyme activity was highest when the temperature was $25^{\circ} \mathrm{C}$.

\section{Comparison of supporter I and supporter II}

According to the conditions described above, the supporter I and the supporter II were obtained separately, and the Scanning electron micrographs of the dried polymer were obtained using KYKY-2800B scanning electron microscope. The results see Figure 3 \& Figure 4. Scanning electron microscopy (SEM) micrographs showed that the supporter $\mathbb{I}$, which simultaneously using methanol solution and nano-calcium carbonate as porogen, had a much more porous surface structure than that of the supporter I only with methanol solution as porogen. In addition, both supporters were used to immobilize enzyme under their optimum conditions, and the results obtained were listed in Table 1. From the results shown in the Table 1, 
the activity of the immobilized enzyme on the supporter II reached a maximum of $519.66 \mathrm{U} / \mathrm{g}$ dry carrier. The obtained enzyme activity was approximately four the values obtained on the supporter I, which could be explained that the porous surface properties of GMA polymer would favor higher adsorption capacity for the enzyme due to increase in the surface area.

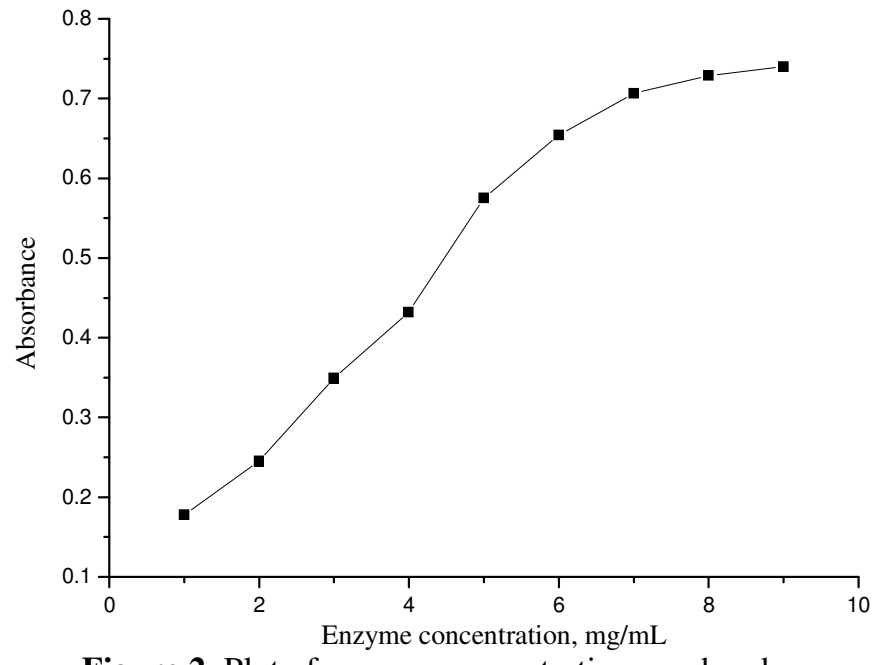

Figure 2. Plot of enzyme concentration $v s$. absorbance.

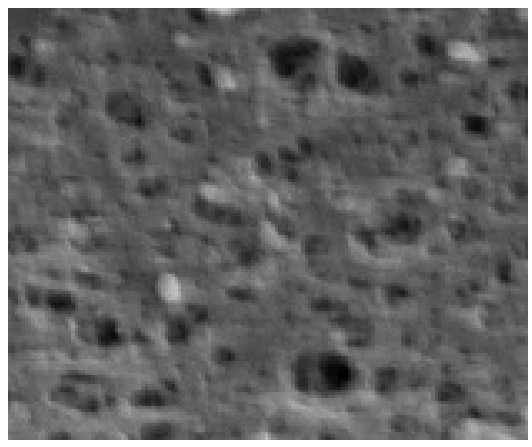

Figure 3. Supporter I

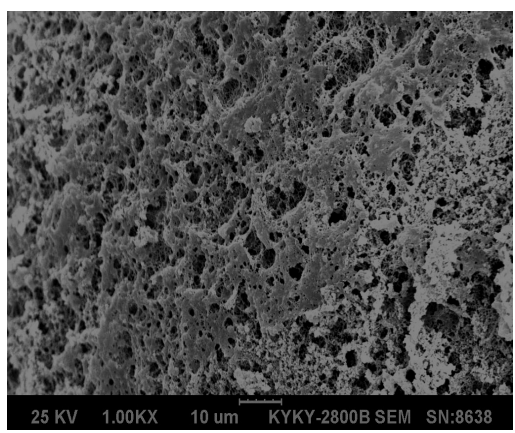

Figure 4. Surpporter II

Table 1. The immobilization results of $\beta$-galactosidase on the supporter I and the supporter II

\begin{tabular}{ccc}
\hline Type of supporter & $\begin{array}{c}\text { Immobilized enzyme activity, } \\
\text { U/g dry supporter }\end{array}$ & $\begin{array}{c}\text { Activity yield } \\
\%\end{array}$ \\
\hline Supporter I & 144.55 & 21.51 \\
Supporter II & 519.66 & 77.33 \\
\hline
\end{tabular}

\section{Conclusion}

In this paper, the reactive, macroporous polyGMA were synthesized simultaneously with methanol aqueous solution and nano-calcium carbonate as porogen by bulk copolymerization and the particles with diameters in the range of 0.30 to $0.45 \mathrm{~mm}$ were taken as carrier after the polymer was smashed. Scanning electron microscopy (SEM) micrographs showed that the supporter II , which simultaneously using liquid and solid 
materials as porogen, had a much more porous surface structure than the supporter I only with liquid solution as porogen. Under the optimum conditions, $\beta$-galactosidase was immobilized on the supporter described above and the enzyme activity bound on the supporter II was much higher than that on the supporter I, which showed that the supporter II was more suitable to immobilize enzyme because of its increase in specific surface. So it could be seen, the polymer as enzyme immobilization carrier, which was prepared with liquid solution as porogen by traditional method, could also be got well using solid and liquid materials as porogen, and it was very useful for industrial application of polymer as enzyme immobilization carrier.

\section{Acknowledgement}

This work was supported by funds from the Natural Science Foundation of Hebei Province (No. B2007000146) and Plan Item of Hebei Province Science-Technology Department No.06213014.

\section{References}

1 Wu L, Gan Y R and Sun Y, Acta Polymerica Sinica, 2003, 10(5), 661.

2 Wu L, Bai S and Sun Y, Biotechnol Prog., 2003, 19, 1300.

3 Bayramoglu G, Kaya B and Arica M Y, Food Chemistry, 2005, 92, 261.

4 Serio Di M, Maturo C, Alteriis De E, Parascandola P, Tesser R and Santacesaria E, Catalysis Today, 2003, 79-80, 333.

5 Vaidya B K, Ingavle G C, Ponrathnam S, Kulkarni B D and Nene S N, Bioresource Technology, 2008, 99, 3623.

6 Mateo C, Torres R, Fern and ez-Lorente G, Ortiz C, Fuentes M and Hidalgo A et al., Biomacromolecules, 2003, 4, 772.

7 Tu W X, Sun S F and Nu S L et al., Food Chemistry, 1998, 64,1.

8 Sun S F, Li X Y and Nu S L et al., J Agric Food Chemistry, 1999, 47, 819.

9 Xue P, Lu G Z and GuoY, Chin J Catal., 2003, 24, 10, 733.

10 Cai H J, Fu D Y, Wang M Y, Zhou X and Tan T W, J Chem Ind Eng (China). 2007, 58(6), 1530. 


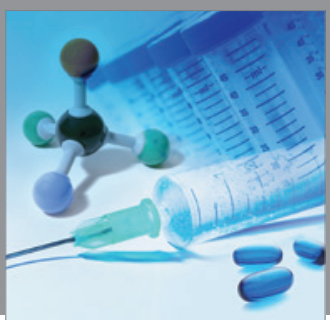

International Journal of

Medicinal Chemistry

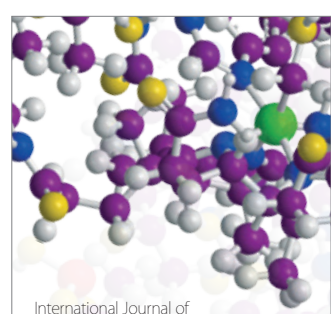

Carbohydrate Chemistry

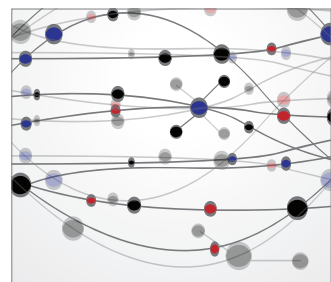

The Scientific World Journal
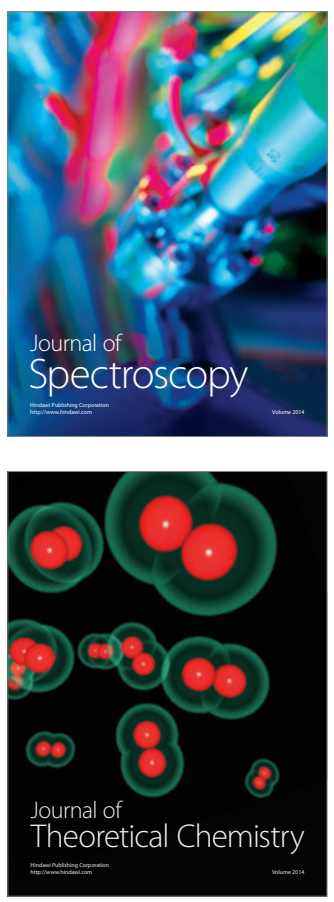
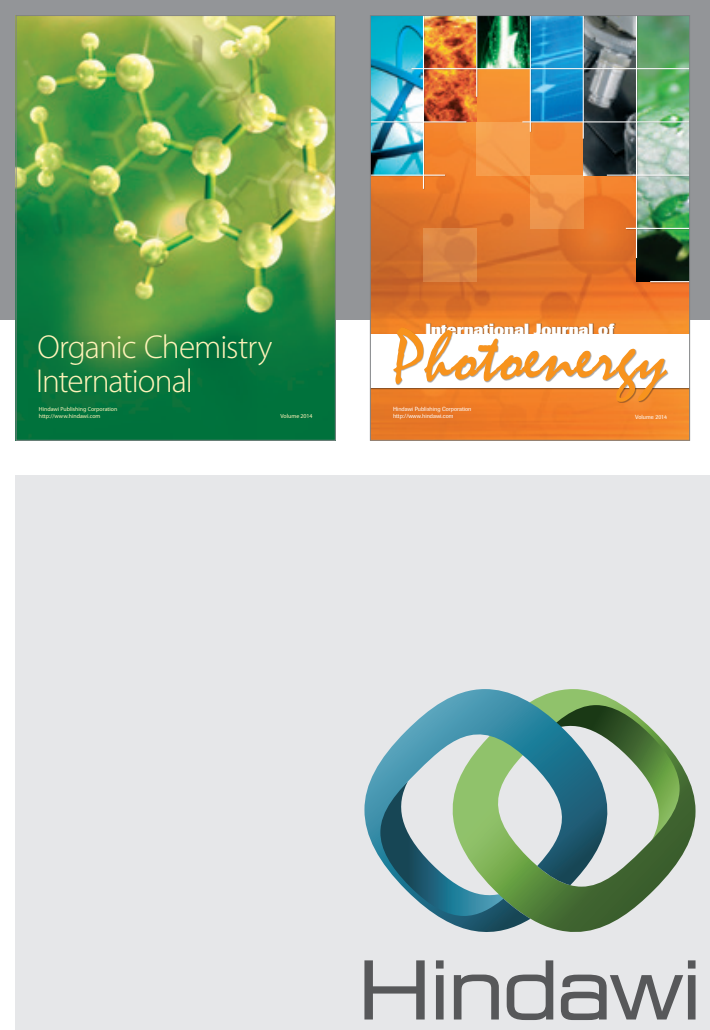

Submit your manuscripts at

http://www.hindawi.com
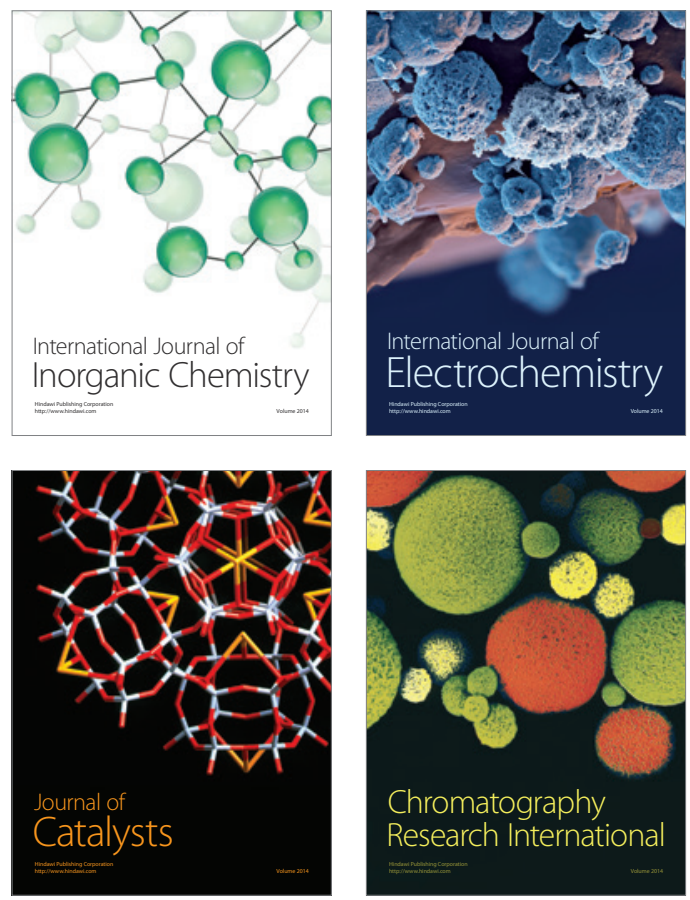
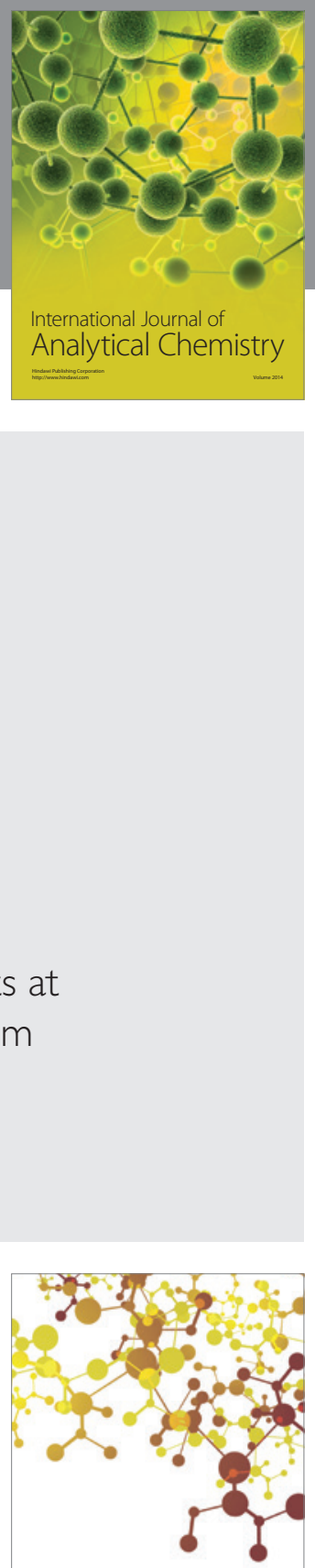

Journal of

Applied Chemistry
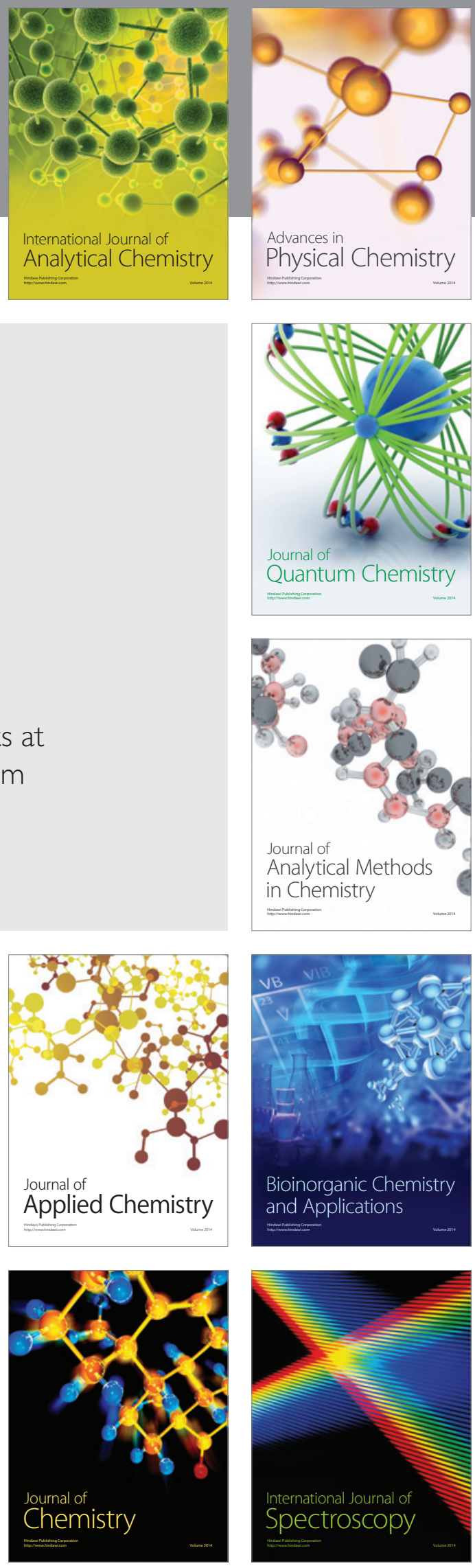